L. V. Kolomiets ${ }^{1}$, DSc, V. F. Orobey ${ }^{2}$, DSc, O. M. Lymarenko ${ }^{2}$, PhD, A. S. Lymarenko ${ }^{1}$

${ }^{1}$ Odesa State Academy of Technical Regulation and Quality, Odesa

${ }^{2}$ Odesa National Polytechnic University, Odesa

\title{
DETERMINATION OF THE STRESSED-DEFORMED STATUS OF THE LOWER JAW NUMEROUS-ANALYTICAL OPTIONAL METHOD OF BOUNDARY ELEMENTS
}

One of the important moving parts of the human skeleton is the lower jaw. People chew food several times a day every day. The lower jaw of a human is the part of the human's skeleton that is most injured. The paper analyzes existing methods for studying the lower jaw of a person, reveals their shortcomings. A review of the results of many years of research shows that the use of the finite element method and the boundary element method is the most promising for determining stress and strain in biosystems. For the first time, a numerical-analytical version of the boundary element method was used to calculate the lower jaw in the form of a flat non-rectangular frame. An algorithm is developed for a numerical-analytical version of the boundary element method and its calculated relationships for flat frame structures. The finite element method is implemented in a modern universal software package. All research results are in good agreement.

Keywords: boundary element method, computer modeling, algorithm, stress-strain state, jaw, flat frame.

Л. В. Коломієць, д.т.н., В. Ф. Оробей, д.т.н., О. М. Лимаренко, к.т.н., А. С. Лимаренко, с.н.с.

\section{ВИЗНАЧЕННЯ НАПРУЖЕНО-ДЕФОРМОВАНОГО СТАНУ НИЖНЬОЇ ЩЕЛЕПИ ЧИСЕЛЬНО-АНАЛІТИЧНИМ ВАРІАНТОМ МЕТОДУ ГРАНИЧНИХ ЕЛЕМЕНТІВ}

Однією з важливих рухливих та найчастіше травмованих частин скелету людини є нижня щелепа. Люди кожен день пережовують їжу по декілька разів на день. Нижня щелепа людини - частина скелета людини, яка найчастіше травмується. Очінювання навантажень на щелепи та характеру їх розподілу є основою для вивчення багатьох питань ортопедії, щелепно-личевої хірургії тощо. 3 появою сучасних комп'ютерів, засобів візуалізачії, розвитком числових методів розрахунку, питання точного визначення напружено-деформованого стану залишасться дуже важливим.

В даний час в розрахунковій практииі все більшого поширення набувають чисельні методи, оскільки вони особливо ефективні для дослідження ортопедичних конструкиій. В роботі виконано аналіз існуючих методів досліджень нижньої щелепи людини, виявлені їх недоліки. Огляд результатів багаторічних досліджень показує, що для визначення напружень $і$ деформачї̈ в біосистемах найбільи перспективним є використання метода скінченних елементів та методів граничних елементів.

В науковому дослідженні розглянуто перший етап формування розрахункової схеми нижньої щелепи - плоска стержнева система у вигляді Г-подібної рами на шарнірних опорах. В статті розглянуто використання сучасного методу комп'ютерного моделювання напружено-деформованого стану кісток обличчя. Представлено алгоритм створення імітачійних комп ютерних моделей напружено-деформованого стану нижньої щелепи. Вперше застосовано чисельно-аналітичний варіант методу граничних елементів до розрахунку нижньої щелепи у вигляді плоскої непрямокутої рами. Розроблено алгоритм чисельно-аналітичного варіанту методу граничних елементів і його розрахункові співвідночення для плоских рамних конструкиії. Метод скінченних елементів реалізовано в сучасному багаточільовому програмному комплексі. Всі результати досліджень добре узгоджуються між собою. В той же час результати чисельно-аналітичного варіанту методу граничних елементів дещо завищені внаслідок, як представлясться, неврахування деформачії розтягування прямолінійних стержнів в початкових рівняннях згинання.

Ключові слова: метод граничних елементів, метод скінченних елементів, комп'ютерне моделювання, алгоритм, напружено-деформований стан, щелепа, плоска рама. 
Л. В. Коломиец, д.т.н., В. Ф. Оробей, д.т.н., А. М. Лимаренко, к.т.н., А. С. Лимаренко

\section{ОПРЕДЕЛЕНИЕ НАПРЯЖЕННО-ДЕФОРМИРОВАННОГО СОСТОЯНИЯ НИЖНЕЙ ЧЕЛЮСТИ ЧИСЛЕННО-АНАЛИТИЧЕСКИМ ВАРИАНТОМ МЕТОДА ГРАНИЧНЫХ ЭЛЕМЕНТОВ}

Одной из важных подвижных частей скелета человека является нижняя челюсть. Люди каждый день пережевывают пишу по несколько раз в день. Оченка нагрузок на челюсти и характера их распределения является основой для изучения многих вопросов ортопедии, челюстно-лищевой хирургии и т.д. В работе выполнен анализ существуюших методов исследований нижней челюсти челове$к а$ вылявлены их недостатки. Обзор результатов многолетних исследований показывает, что для определения напряжений и деформачий в биосистемах наиболее перспективным является использование метода конечных элементов и метода граничных элементов. Впервые применен численноаналитический вариант метода граничных элементов для расчета нижней челюсти в виде плоской непрямоугольной рамы. Разработан алгоритм численно-аналитического варианта метода граничных элементов и его расчетные соотношения для плоских рамных конструкций. Метод конечных элементов реализован в современном универсальном программном комплексе. Все результаты исследований хорошо согласуются между собой.

Ключевые слова: числові методи, метод граничных элементов, метод конечных элементов, компьютерное моделирование, алгоритм, напряженно-деформированное состояние, челюсть, плоская рама.

\section{$\underline{\text { DOI } 10.32684 / 2412-5288-2019-1-14-33-38}$}

\section{Introduction}

The lower jaw of a human is the part of the human's skeleton that is most injured.

The load on the jaws and the nature of their distribution, in the norm, is the basis for the study of many issues of orthopedics, maxillofacial surgery, etc.

In the work the method of boundary elements is applied to the calculation of the lower jaw of a person (Fig. 1).

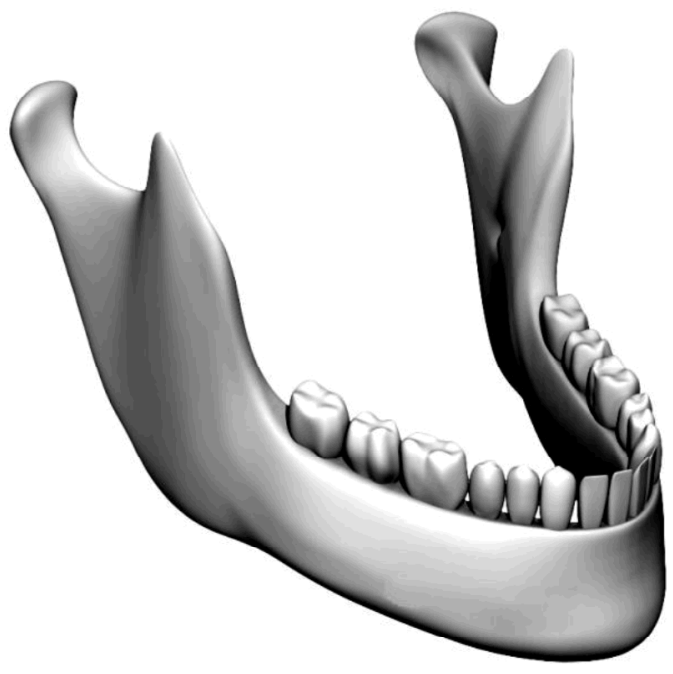

Figure 1 - General view of the Lower Jaw

Billions of people chew their food every day, several times a day; thousands of scientists are exploring this process in our time and in the past. The question of the exact determination of stress-strain state (SSS) remains relevant.

In the process of bite (with the inclusion of two front incisors), the lower jaw can be represented in the form of a symmetrical frame with a symmetrical action of chewing load, which allows to consider only half of the system, as a flat frame [1-4].

The scheme of the lower jaw is presented in Fig. 2 in the form of a flat frame is a mechanism that can rotate freely around the hinge until any restriction occurs. In this case, any tooth-antagonist may be a limiter of motion, which comes in contact with the tooth or through the food breast.

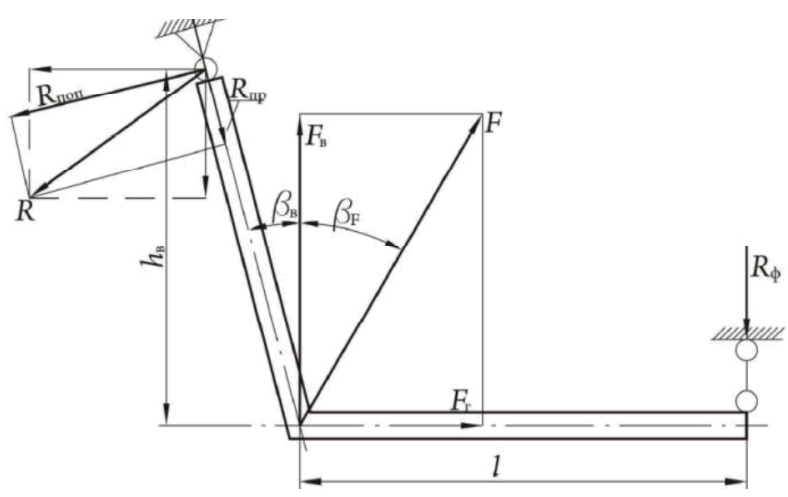

Figure 2 - Estimated diagram of the lower jaw

\section{Analysis of the publications}

In the case of a bite, following the work partly [5], we represent the lower jaw in the form of a flat frame (Fig. 2). 
Articular jaw head is a classic hinge, like in anatomy and by the peculiarities of functioning. Before contact with the tooth-antagonist, the lower jaw may be considered as the simplest mechanism of lever. If there is movement restriction in the area of the incisors, it is a flat statically distinctive frame [59], pivotally supported at two points (in the area of the articular head and in the area of the incisors), which is schematically shown in Fig. 2 in the form of fixed and movable hinges.

The reaction that occurs in a fixed hinge, can be represented as two components (for example, horizontal and vertical, or transverse and longitudinal), and in the movable hinge as one component.

In contrast to the work [4], it is most expedient to take the magnitude of the chewing load $F$ as an external force, which will be the function of reactions in the supports and the internal force factors in the jaw sections.

At present, numerous methods are becoming more widespread in computational practice, because they are especially effective for the study of orthopedic structures.

These methods are based on discrete calculation schemes. One of the most common numerical methods today is the finite element method (FEM), which implies a clear approximation of the solution in small subdomains.

Coordinate functions of different order are used for interpolation.

A great quality of literature is devoted to the theoretical aspects (FEM) $[13,14]$.

Most modern universal software packages ANSYS, Cosmos Works, NASTRAN and others work on the basis of FEM.

Simultaneously with FEM, in recent years, another numerical method has been actively developed - the boundary element method (BEM), where the basis is not the usual difference schemes, but the integral equation of the problem and its fundamental solutions [13, 14].

Not only the whole area of an object is subjected to sampling at the BEM, but only its boundary at which the necessary parameters are determined from the system of linear algebraic equations, and the state at the internal points is calculated from the integral equations.

It is known that the stiffness matrix of the elastic modulus can be constructed on the basis of BEM ratios [14].

\section{Main part}

To analyze the stress-strain state in the lower jaw, the chewing load $\mathrm{F}$ must be divided into two components: horizontal and vertical.

In further study of the issues of strength and rigidity of the jaw, it is necessary to know the basic geometrical characteristics of the section: static moments, moments of inertia (axial) and moments of resistance.

Compliance with the model requirements and the actual jaw when schematizing, the jaw cross sections causes some difficulties. For axial loads (tensile or compressive), the cross-sectional area must be achieved evenly, and for transverse forces (in shear, bending, and torsion), this applies to the moments of inertia and the height of the section.

The analysis of the questions of the design schemes shows that among the simple canonical flat sections (rectangle, circle and ellipse), the shape of the ellipse most fully characterizes the contours of the cross sections of the mandible.

In scientific research, it is necessary to take into account the difference in mechanical characteristics for compact and spongy bone [10-12].

The ratio of their density, introduced in [4], does not, in our opinion, fully reflect the essence of the question. After all, in the calculation formulas for the estimation of stiffness (displacements) and strength (stresses), the density of structural components is not taken into account at all.

Note that in the technique of calculating the characteristics of stiffness and strength of composite structures, parts of which have different stiffness, use the method of reduction coefficients. Its essence for materials that obey the Hooke law is to introduce a reduction coefficient as the ratio of the modulus of elasticity of the materials.

In reduced geometric characteristics (areas, moments of inertia, etc.), the areas of the elements are conditionally reduced as much as their modulus is smaller than the modulus of elasticity of the base material. Described above should be taken into account when performing any type of research and calculation, especially when using numerical methods. Consider the application of a numerically analytical variant of the boundary element method to the calculation of the mandible as a flat G-shaped frame.

Form the BEM equation according to the scheme for a flat rod system

$$
\mathrm{Y}(l)=\mathrm{A}(l) \mathrm{X}(0)+\mathrm{B}(l) \rightarrow \mathrm{A}(l) \mathrm{X}(0)-\mathrm{Y}(l)=\mathrm{B}(l) \rightarrow \mathrm{A}_{*}(l) \mathrm{X}_{*}(0, l)=-\mathrm{B}(l) .
$$

For straight lines, bending equation with normal forces 


\begin{tabular}{|c|}
\hline$E I v(x)$ \\
\hline$E I \varphi(x)$ \\
\hline$M(x)$ \\
\hline$Q(x)$ \\
\hline$N(x)$ \\
\hline
\end{tabular}$=$\begin{tabular}{|c|c|c|c|c|}
\hline 1 & $x$ & $x^{2} / 2$ & $x^{3} / 6$ & \\
\hline & 1 & $x$ & $x^{2} / 2$ & \\
\hline & & 1 & $x$ & \\
\hline & & & 1 & \\
\hline & & & & 1 \\
\hline
\end{tabular}

Limit parameters are determined from the system of linear algebraic equations (1), and the state of the structure at internal points is determined by the equations (2).

The results of the BEM calculation are summarized in Table 1.

Finite element calculation

The ANSYS program was selected to implement the FEM algorithm.

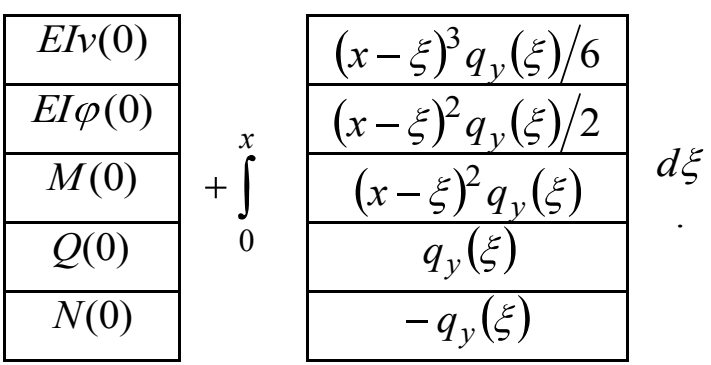

Table 1 - Results of the calculation of the design of the lower jaw

\begin{tabular}{|c|c|c|c|c|c|c|}
\hline WCF & BEM & $\begin{array}{c}\text { Engineering } \\
\text { method } \\
{[1]}\end{array}$ & $\begin{array}{c}\text { FEM } \\
(10 \mathrm{ce})\end{array}$ & $\begin{array}{c}\text { FEM } \\
(40 \mathrm{ce})\end{array}$ & $\begin{array}{c}\text { FEM } \\
(100 \mathrm{ce})\end{array}$ & $\begin{array}{c}\text { FEM } \\
(1000 \mathrm{ce})\end{array}$ \\
\hline$N_{z_{1}}(\mathrm{\kappa H})$ & 1,383 & & 1,322 & 1,349 & 1,354 & 1,357 \\
\hline$Q_{y_{1}}(\mathrm{\kappa H})$ & 1,169 & & 1,160 & 1,161 & 1,161 & 1,161 \\
\hline$M_{x_{1}}(\kappa \mathrm{Hм})$ & 0,642 & 0,618 & 0,6105 & 0,613 & 0,613 & 0,613 \\
\hline$N_{z_{2}}(\kappa \mathrm{H})$ & 0,741 & & 0,689 & 0,668 & 0,678 & 0,684 \\
\hline$Q_{y_{2}}(\mathrm{\kappa H})$ & 0,36 & & 0,3011 & 0,30 & 0,303 & 0,304 \\
\hline$M_{x_{2}}(\kappa \mathrm{Hм})$ & 1,110 & 0,986 & 1,108 & 1,108 & 1,109 & 1,108 \\
\hline$N_{z_{3}}(\mathrm{\kappa H})$ & 2,345 & & 2,284 & 2,3 & 2,313 & 2,316 \\
\hline$Q_{y_{3}}(\mathrm{\kappa H})$ & 1,138 & & 1,130 & 1,131 & 1,131 & 1,131 \\
\hline$M_{x_{3}}(\kappa \mathrm{Hм})$ & 1,547 & 0,5247 & 1,517 & 1,5192 & 1,519 & 1,519 \\
\hline
\end{tabular}

The results on the FEM when crushing a finite element grid are presented in table 1 .

The comparisons of these calculations show that the FEM results can be considered the most reliable. They agree well with the engineering method of calculating flat G-shaped frames.

At the same time, the results of the BEM are somewhat overstated due to the fact that the deformation of the stretching of the straight bars in the initial bending equations does not seem to be taken into account.

\section{Conclusions:}

1. The analysis of existing methods of modeling the construction of the lower jaw was performed. The disadvantages are indicated.
The calculation model is approximated by the BEAM3 element from the ANSYS finite element library. This is a two-node element used mainly for the calculation of rod structures.

As a result of the FEM calculation, for each variant of EM partitioning, a deformed shape of the system, normal force and transverse forces, and flexural moments are obtained. The calculation results at $\mathrm{n}>1000$ have not been specified.

2. It is shown that the methods of finite and boundary elements are the most effective approaches for calculating the stress-strain state of the lower jaw.

3. The algorithm of the boundary element method and its calculated ratios are presented as a result of integrating the differential equations of the static of the rod systems.

4. The finite element method is implemented in Ansys.

5. The calculations of the VAT of the lower jaw as a flat L-shaped frame according to the FEM and BEM algorithms were performed.

The calculation results are in good agreement with each other, which indicate the reliability of the created models and calculations. 


\section{References:}

1. Mandziuk T. Do modeliuvannia biomekhanichnykh konstruktsii z miakymy prosharkamy [For modeling of biomechanical structures with soft layers] / T. Mandziuk, V. Vovk // Visnyk Lvivskoho Universytetu. Seriia prykladna matematyka ta informatyka. - 2011. - Vyp. 17. S. $85-93$.

2. Shelkovnikov E. Yu. Trexmernoe matematicheskoe modelirovanie napryazhennodeformirovannogo sostoyaniya zuba i plomby [Three-demantional mathematical modeling of the stress-strain state of the tooth and filling] / E. Yu. Shelkovnikov, A. I. Kirillov, S. M. Efremov, T. L. Redinova, A. A. Timofeev, T. Yu. Meteleva // Polzunovskij vestnik. - 2014. - № 2. - S. 54 - 58 .

3. Zholudev S. E. Ob odnoj zadache optimizacii formy $\mathrm{V}$ stomatologii [About one problem of shape optimization in dentistry] / S. E. Zholudev, I. N. Kandoba // Rossijskij zhurnal biomexaniki. - 2017. - T. 21. - № 2. - S. 135-146. DOI: 10.15593/RZhBiomeh/2017.2.02.

4. Leonenko P. V. Skincheno-elementnyi analiz imitatsiinoi trokhvymirnoi modeli biomekhanichnoi systemy «kistkova tkanyna dentalnyi implantat - suprakonstruktsiia» [Elemental analysis of simulation three-dimensional model of biomechanical system «bone tissue - dental implant - superconstraction»] / P. V. Leonenko, V. O. Yeshchenko // Visnyk Natsionalnoho tekhnichnoho universytetu Ukrainy «Kyivskyi politekhnichnyi instytut». Seriia mashynobuduvannia. - 2012. - \# 65. - S. $105-109$.

5. Loxov V. A. Sravnitel'naya ocenka urovnya funkcional'nyx nagruzhenij, razvivayushhixsya $\mathrm{v}$ e'mali zubov pri ispol'zovanii razlichnyx tipov sportivnyx zubnyx shin [Comparative assessment of the level of functional loads developing in tooth enamel using various types of sports dental tires] / V. A. Loxov, N. B. Astashina, E. S. Sergeeva, A. F. Merzlyakov, A. A. Bajdarov // Rossijskij zhurnal biomexaniki. 2017. T. 21 - № 2 - S. 211-217.

DOI: 10.15593/RZhBiomeh/2017.2.08.

6. Stankevich A. N. Nhe history and development prospects of the methods for solving multidimensional problems of structural mechanics. ISSN 1997-0935. Vestnik MGSU. - 2015. - № 12. P. 76-91.

7. Orobey V. Boundaru element metod in problems of plate elements bending of engineering structures[Text] / V. Orobey, L. Kolomiets, O. Lymarenko // Metalurgical and Mining Industry. - 2015. - 7(4). - P. 295-302.

8. Velychko O. A comparative analysis of the assessment results of the competence of technical experts by different methods / Velychko O., Gordiyenko T., Kolomiets L. // Eastern-European Journal of Enterprise Technologies. - 2017. - 3 (88). - P. 4-10. DOI: 10.15587/1729-4061.2017.106825.

9. Kozhushko, V. P. Raschet pryamougol'noj plastiny, dve smezhnye storony kotoroj zashhemleny, a dve drugie smezhnye storony sharnirno operty [Calculation of a rectangular plate, two adjacent sides of which are pinched, and two other adjacent sides are pivotally supported] / V. P. Kozhushko. - Vestnik Xar'kovskogo nac. avtom.-dorozhn. un-ta. - Xar'kov, 2014. - Vyp. 67. - S. 119-123.

10. Kim C. K., Hwang M. H. Non-Linear Analysis of Skew Thin Plate by Finite Difference Method / Journal of Mechanical Science and Technology. - 2012, vol. 26. - no. 4. - P. 11271132. DOI: http://dx.doi.org/10.1007/s12206-0120226-9.

11. Aizikovich S., Vasiliev A., Trubchik I., Evich L., Ambalova E., Sevostianov I. Analytical Solution for the Bending of a Plate on a Functionally Graded Layer of Complex Structure. Advanced Structured Materials. - 2011, vol. 15, P. 15 - 28. DOI: http://dx.doi.org/10.1007/978-3-642-2185522.

12. Malanchuk V. Vyvchennia biomekhaniky nyzhnoi shchelepy na tryvymirnykh kompiuternykh modeliakh metodom skinchennykh elementiv [Study of lower jaw biomechanics on three-dimensional computer models by finite element method] / V. O. Malanchuk, M. H. Kryshchuk, A. V. Kopchak // Visnyk stomatolohii. - 2009. - \# 3. - S. 56-62.

13. Orobey V. Mathematical modeling of the stressed-deformed state of circular arches of specialized cranes [Text] / V. Orobey, O. Daschenko, L. Kolomiets, O. Lymarenko, Y. Ovcharov // Eastern European Journal of Enterprise Technologies. - 2017. - 5/8 (89). P. 4-11.

14. Orobey V. Stability of structural elements of special lifting mechanisms in the form of circular arches [Text] / V. Orobey, O. Daschenko, L. Kolomiets, O. Lymarenko // Eastern European Journal of Enterprise Technologies. - 2018. 2/7(92). - P. 4-10.

\section{Список використаних джерел}

1. Мандзюк Т. До моделювання біомеханічних конструкцій 3 м'якими прошарками / Т. Мандзюк, В. Вовк // Вісник Львівського Університету. Серія прикладна математика та інформатика. - 2011. - Вип. 17. C. $85-93$.

2. Шелковников Е. Ю. Трехмерное математическое моделирование напряженно- 
деформированного состояния зуба и пломбы / Е. Ю. Шелковников, А. И. Кириллов, С. М. Ефремов, Т. Л. Рединова, А. А. Тимофеев, Т. Ю. Метелева // Ползуновский вестник. - 2014. - № 2. - С. $54-58$.

3. Жолудев С.Е. Об одной задаче оптимизации формы в стоматологии / С. Е. Жолудев, И. Н. Кандоба // Российский журнал биомеханики. - 2017. - Т. 21 - № 2. C. 135-146. DOI: 10.15593/RZhBiomeh/2017.2.02.

4. Леоненко П. В. Скінчено-елементний аналіз імітаційної трьохвимірної моделі біомеханічної системи «кісткова тканина дентальний імплантат - супраконструкція» / П.В.Леоненко, В. О. Сщенко // Вісник Національного технічного університету України «Київський політехнічний інститут». Серія машинобудування. - 2012. - № 65. - С. 105 - 109.

5. Лохов В. А. Сравнительная оценка уровня функциональных нагружений, развивающихся в эмали зубов при использовании различных типов спортивных зубных шин / В. А. Лохов, Н. Б. Асташина, Е. С. Сергеева, А. Ф. Мерзляков, А. А. Байдаров // Российский журнал биомеханики - 2017. T. 21 - № 2 - C. 211-217.

DOI: 10.15593/RZhBiomeh/2017.2.08.

6. Stankevich A. N. Nhe history and development prospects of the methods for solving multidimensional problems of structural mechanics. ISSN 1997-0935. Vestnik MGSU. 2015. - № 12. P. 76-91.

7. Orobey V. Boundaru element metod in problems of plate elements bending of engineering structures[Text] / V. Orobey, L. Kolomiets, O. Lymarenko // Metalurgical and Mining Industry. 2015. - 7(4). - P. 295-302.

8. Velychko O. A comparative analysis of the assessment results of the competence of technical experts by different methods / Velychko O., Gordiyenko T., Kolomiets L. // Eastern-European
Journal of Enterprise Technologies. - 2017. - 3 (88). - P. 4-10. DOI: 10.15587/1729-4061.2017.106825.

9. Кожушко, В. П. Расчет прямоугольной пластины, две смежные стороны которой защемлены, а две другие смежные стороны шарнирно оперты / В. П. Кожушко. - Вестник Харьковского нац. автом.-дорожн. ун-та. Харьков, 2014. - Вып. 67. - С. 119-123.

10. Kim C. K., Hwang M. H. Non-Linear Analysis of Skew Thin Plate by Finite Difference Method / Journal of Mechanical Science and Technology. - 2012, vol. 26. - no. 4. - P. 11271132. DOI: http://dx.doi.org/10.1007/s12206-0120226-9.

11. Aizikovich S., Vasiliev A., Trubchik I., Evich L., Ambalova E., Sevostianov I. Analytical Solution for the Bending of a Plate on a Functionally Graded Layer of Complex Structure. Advanced Structured Materials. - 2011. - vol. 15. - P. 15 - 28. DOI: http://dx.doi.org/10.1007/978-3-642-218552_2.

12. Маланчук В. Вивчення біомеханіки нижньої щелепи на тривимірних комп'ютерних моделях методом скінченних елементів / В. О. Маланчук, М. Г. Крищук, А. В. Копчак // Вісник стоматології. - 2009. - № 3. - С. 56-62.

13. Orobey V. Mathematical modeling of the stressed-deformed state of circular arches of specialized cranes [Text] / V. Orobey, O. Daschenko, L. Kolomiets, O. Lymarenko, Y. Ovcharov // Eastern European Journal of Enterprise Technologies. - 2017. - 5/8 (89). - P. 411.

14. Orobey V. Stability of structural elements of special lifting mechanisms in the form of circular arches [Text] / V. Orobey, O. Daschenko, L. Kolomiets, O. Lymarenko // Eastern European Journal of Enterprise Technologies. - 2018. 2/7(92). - P. 4-10.

Надійшла до редакиії 03.04.2019. 